\title{
Shakespeare, lieu de mémoire
}

\section{Clara Calvo}

\section{(2) OpenEdition \\ Journals}

\section{Electronic version}

URL: http://journals.openedition.org/shakespeare/1961

DOI: 10.4000/shakespeare.1961

ISSN: 2271-6424

\section{Publisher}

Société Française Shakespeare

\section{Printed version}

Date of publication: 1 April 2013

Number of pages: 209-224

ISBN: 2-9521475-9-0

\section{Electronic reference}

Clara Calvo, "Shakespeare, lieu de mémoire », Actes des congrès de la Société française Shakespeare [Online], 30 | 2013, Online since 03 April 2013, connection on 01 May 2019. URL : http:// journals.openedition.org/shakespeare/1961 ; DOI : 10.4000/shakespeare.1961 


\section{Shakespeare et la mémoire}

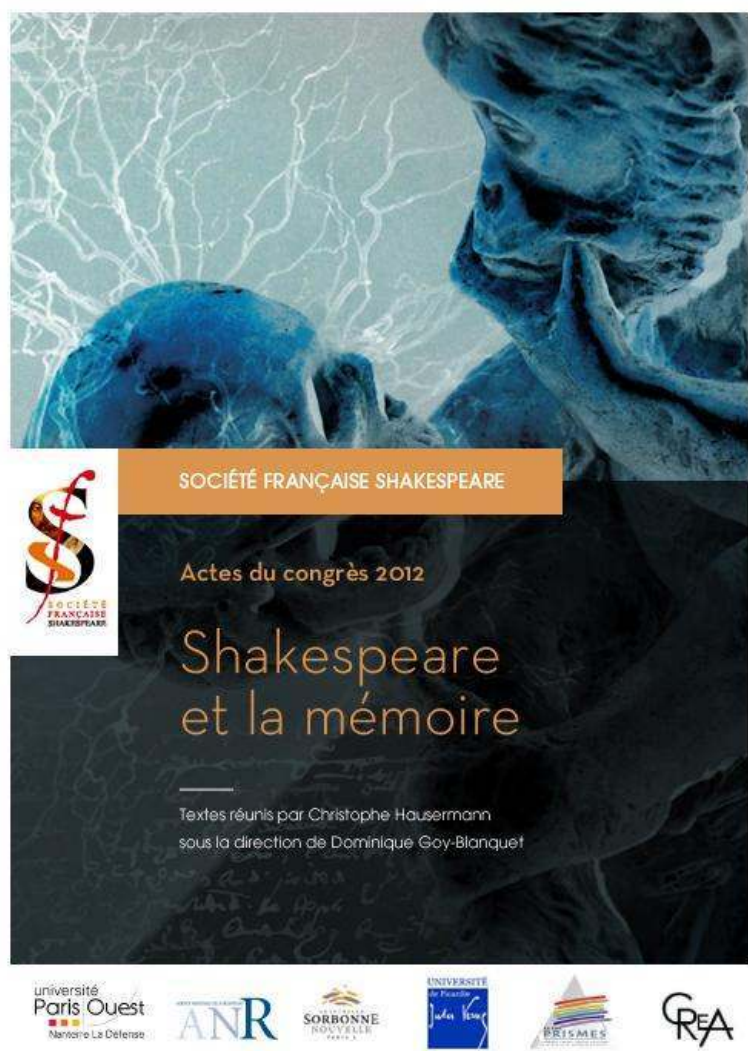

actes du Congrès

organisé par la

SOCIÉTÉ FRANÇAISE SHAKESPEARE

les 22, 23 et 24 mars 2012

textes réunis par

Christophe HAUSERMANN

sous la direction de

Dominique GoY-BLANQUET 


\section{COUVERTURE}

d'après l'affiche de Claire Colombet

conception graphique et logo

Pierre Kapitaniak

mise en page et corrections

Christophe Hausermann

(C) 2012 Société Française Shakespeare

Institut du Monde Anglophone

Université de Paris III - Sorbonne Nouvelle

5 rue de l'École de Médecine 75006 Paris

www.societefrancaiseshakespeare.org

Tous droits de traduction, de reproduction et d'adaptation réservés pour tous les pays 
SHAKESPEARE, LIEU DE MEMOIRE

Clara Calvo

\begin{abstract}
Although Shakespeare is buried in Stratford's Holy Trinity Church and not in London's Westminster Abbey, his monument in the English Pantheon of grands hommes, metonymically known as Poets' Corner, seems to have enjoyed a more lasting afterlife, at least in popular culture, than the bust placed over his grave. Scheemakers and Kent's monument, containing what is probably Shakespeare's most iconic statue, is a cenotaph, a selfadvertised empty tomb, which works as a site of memory but hardly as a site of mourning. This paper looks at Shakespeare's monuments not with the eyes of the literary tourist but those of a cultural anthropologist eager to explore how memory studies can improve our understanding of the cultures of Shakespearean commemoration. The paper will also show how popular culture tends to reprocess and appropriate lieux de mémoire and how Shakespeare, as an English grand homme, problematises Pierre Nora's distinction between lieu matériel and lieu immatériel.
\end{abstract}

Bien que Shakespeare fût enterré à Holy Trinity Church à Stratford et non à l'Abbaye de Westminster à Londres, son monument dans le Panthéon britannique des grands hommes, appelé par métonymie Poets' Corner, semble avoir bénéficié d'une plus grande longévité, du moins dans la culture populaire, que le buste placé sur sa tombe. Le monument érigé par Kent et Scheemakers, où se dresse la statue la plus représentative de Shakespeare, est un cénotaphe, une tombe qui se présente comme vide et qui fait office de site de mémoire à défaut de site de deuil. Cet article analyse les monuments dédiés à Shakespeare non pas avec le regard du touriste lettré, mais avec celui de l'amateur d'anthropologie culturelle, avide de savoir comment les études consacrées à la mémoire peuvent nous permettre de mieux comprendre les cultures de la commémoration shakespearienne. Cet article entend démontrer comment la culture populaire tend à transformer et à s'approprier les « lieux de mémoire » et comment Shakespeare, en tant que grand homme britannique, soulève la question de la distinction entre les notions de « lieu matériel » et « lieu immatériel » développée par Pierre Nora.

$\mathrm{A}$

ny Shakespearean flâneur who visits the empty site of the long gone Shakespeare's statue by Fournier on boulevard Haussmann (Fig. 1) may combine the visit to this peculiar symbolic site of Shakespearean memory in Paris with a visit to two other sites of literary and collective memory. ${ }^{1}$ From boulevard Haussmann, after visiting the site of the statue that is no longer there in search of some of its genius loci, one can take a detour to visit another memory site, the plaque for Proust on the façade of 102 boulevard Haussmann, where he lived just before and during World War One.

${ }^{1}$ For Shakespeare's statue in Paris, see Ton Hoenselaars, "The Pierre Fournier Shakespeare Statue in the City of Paris, 1888-1941. Reflections on Commemoration, Cosmopolitanism, and Urban Development during the Third Republic," Shakespeare-Jahrbuch 147 (2011), p. 105-23. In this paper, I would like to acknowledge my debt towards French cultural history in general and to Pierre Nora and his collaborators in particular. Research for this paper was made possible thanks to Research Project FFI2011-24347, "Shakespeare and the Cultures of Commemoration II: Remembering Shakespeare", financed by the Spanish Research Agency MEC-ANEP. 


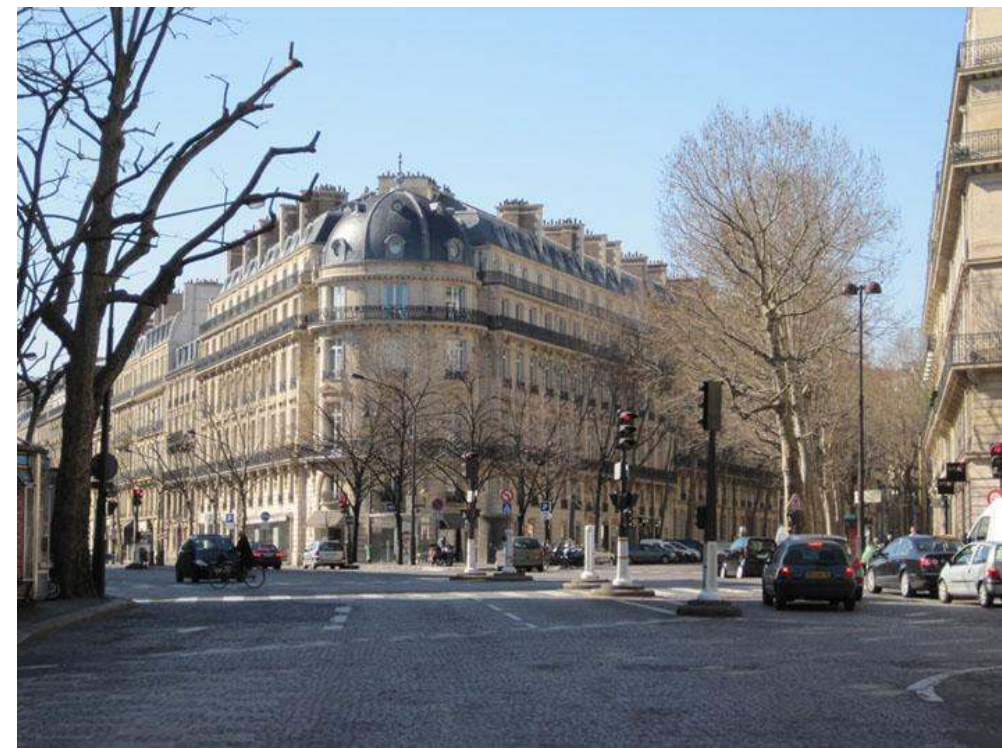

Figure 1: Boulevard Haussmann

A few minutes' walk from this site, taking a turn into la rue Pasquier, one stumbles upon an elegant-looking chapel that turns out to be yet another site of memory, an empty grave, a self-declared cenotaph. The beauty of the chapelle expiatoire for Louis XVI and Marie-Antoinette, and its hollowness, suggests how paradoxical cenotaphs are, and how oddly they question our ways of commemorating national figures and great men. Cenotaphs are memorials that simultaneously memorialise the body that is not there and trigger remembrance of the actual grave where the body lies. As a lieu de mémoire, this chapelle invokes the memory of St. Denis in the same way that the Shakespeare cenotaph in Poets' Corner $^{2}$ is symbolically linked to his grave in Stratford's Holy Trinity Church (Fig. 2), reminding us of the multiple ways in which Shakespeare is remembered. Taking its cue from these reflections, this paper aims to show that the multi-sided notion of the lieu de mémoire, or "site of

${ }^{2}$ http://www.westminster-abbey.org/visit-us/highlights/poets-corner 
memory" can help us understand how societies remember, and sometimes also how societies forget, through Shakespeare.

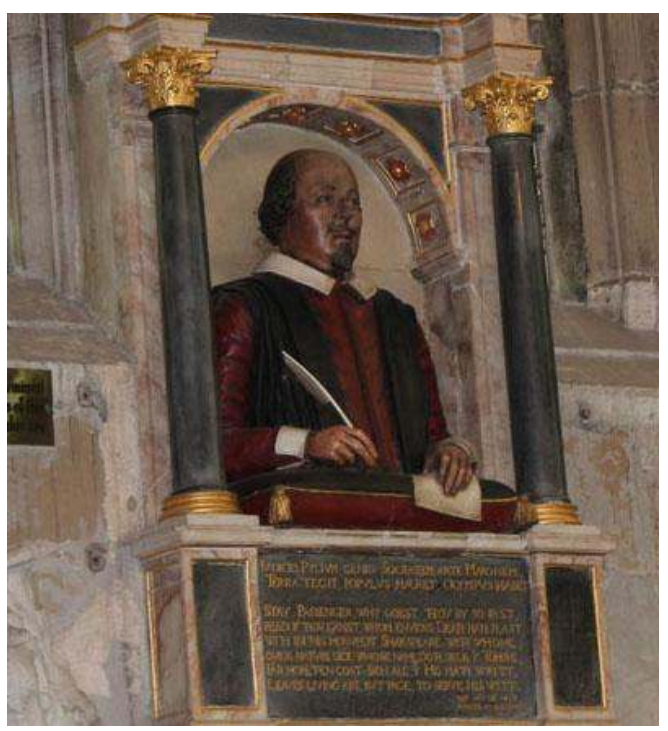

Figure 2: Shakespeare Memorial in Stratford's Holy Trinity Church

In his monumental work, Pierre Nora established a typology of three types of sites of memory: (a) descriptive sites of division; (b) constitutive sites of tradition; and (c) symbolic sites of identity. ${ }^{3}$ Although all sites of memory are symbolic by definition, symbolic sites have an added symbolic dimension that turns them into sites of identity of a community or a nation. Like the national emblem, the national anthem, Versailles or Buckingham Palace, the Eiffel Tower or Big Ben, Shakespeare is a symbolic site of British and Anglophone national identity. As Michael Dobson has shown, Shakespeare became a national poet, a symbolic site of Englishness, as a result of a process of canonization that took place along the $18^{\text {th }}$ century and which ran

3 Pierre Nora, Les Lieux de mémoire, 3 vols, La République, La Nation, Les France, Paris, Gallimard, 1984, 1987, 1992. 
parallel to a rejection of French neoclassical poetics. ${ }^{4}$ The process was already rather advanced when in 1814, Jane Austen made Henry Crawford in Mansfield Park say that Shakespeare is "a part of an Englishman's constitution" and Edmund Bertram add "we all talk Shakespeare, use his similes, and describe with his descriptions." 5 As Austen's novel shows, by the onset of the $19^{\text {th }}$ century, Shakespeare, metonymically linked to the English language, had already become a symbolic site of anglophone identity.

To his Cartesian typology of lieux de mémoire into sites of division, tradition and identity, Pierre Nora has added a distinction between imposed and constructed sites of memory. Imposed sites are official state symbols, whose symbolic and memorial intention is inscribed in the site itself, and which, like the Panthéon or the Eiffel Tower, were conceived from the start as monuments and symbols. Constructed sites of memory, instead, are symbols, like the Gallic cock, Joan of Arc or philosopher Descartes, which have become durable, permanent sites of memory, as Nora explains, through "unforeseen mechanisms, combination of circumstances, the passage of time, human effort and history itself." 6 As a lieu de mémoire, Shakespeare is, like Joan of Arc or Descartes, a constructed symbol. This paper argues that the processes that turned the shepherdess of Domrémy or the "fireside philosopher" into durable symbols of Frenchness are similar to the processes by which the late Elizabethan theatrical entrepreneur and the Jacobean landowner became a durable symbol of Englishness.

According to Nora, imposed symbols only require the historian to recount their history, whereas constructed symbols, in spite of the vast literature already produced recounting their history, are still in need of historians eager to dissect the various layers of memory that they contain. Jonathan Bate, Michael Dobson, Graham Holderness, Gary Taylor and countless others have recounted the history of Shakespeare as lieu de mémoire but the layers of collective memory that contributed, and still contribute today, to memorialise

\footnotetext{
${ }^{4}$ Michael Dobson, The Making of the National Poet: Adaptation and Authorship, 166o1769, Oxford, Clarendon, 1992.

5 Jane Austen, Mansfield Park, ed. R.W. Chapman, $3^{\text {rd }}$ edition, London, Oxford University Press, 1934, p. 338.

6 Pierre Nora, Realms of Memory, Vol. III, New York: Columbia University Press, 1992, p. $x$.
} 
Shakespeare still stand in need of dissection. ${ }^{7}$ For their history of Shakespeare as symbolic site of national identity, Shakespearean scholars have looked into the archive, but for my reading of Shakespeare as English lieu de mémoire, the archive needs to be supplemented with what Diana Taylor has labelled the repertoire. ${ }^{8}$ The repertoire is opposed to the archive in so far as it consists of the repeated enactment of a series of acts or rituals, the reiterated "embodied" and social behaviour that transmits knowledge, cultural memory and collective identity from one group to another or from one generation to the next.

\section{Memorialising Shakespeare}

If Shakespeare is a constructed lieu de mémoire, what forces or agents, what reiterated rituals or repeated acts have contributed to shape its symbolic nature? Or to put the question differently, how is Shakespeare remembered, how is Shakespeare memorialised? The question may sound simple enough, but the answers are multiple. Shakespeare is commemorated in centenaries and anniversaries but he is memorialised daily in theatrical and educational practice, through the reading, discussing and performing of the plays in venues that range from conventional stages to prisons and the open air. Since his death, his memory has been perpetuated in portraits, statues and editions of his works, but also through adaptation and appropriation in diverse media, from plays, novels, poems and films to stamps, advertising, comic books, animated cartoons and graphic novels. Throughout the centuries, quotations from the plays and sonnets have helped to preserve his memory even for those who have never read and will never read a single scene from one of the plays. Given its growing presence in global culture, the memorialisation of Shakespeare offers an intriguing case for a study of the workings of collective cultural

7 See Jonathan Bate, The Genius of Shakespeare, London, Picador, 1997; Dobson, The Making of the National Poet; Graham Holderness, ed., The Shakespeare Myth, Manchester, Manchester University Press, 1988; Gary Taylor, Reinventing Shakespeare: A Cultural History from the Restoration to the Present, New York \& London, Weidenfield \& Nicholson, 1989.

8 Diana Taylor, The Archive and the Repertoire: Performing Cultural Memory in the Americas, Durham, Duke University Press, 2003. See also, "Performance and Intangible Cultural Heritage", in The Cambridge Companion to Performance Studies, ed. Tracy C. Davis, Cambridge, C.U.P., 2008, p. 91-104. 
memory. It also offers a vantage point to explore the ways in which societies choose to commemorate their great men.

Practices of commemoration are constrained by contextual factors and are therefore dependent on time and space, on historical periods and on the way nations often reinvent their own past. Studying the practices of commemoration peculiar to a given time and place provides an insight into the ideological forces that shape the collective cultural memory of a country at a given time. This paper is mostly concerned with practices of memorialisation that involve a location, that are connected to a place, a space that becomes a site of memory through its particular relevance for collective remembrance. My concern here is to explore the materiality of some of the sites of Shakespearean memory that are topographically defined. These sites of memory, amongst which the example par excellence is the Birthplace, centrally include statues, portraits, memorials, graves, and cenotaphs but also, in a sense, exhibitions.

Exhibitions may seem at first sight not to belong in this list unlike statues, portraits or graves, temporality is at the basis of their condition of existence. Unlike memorials, they are not meant to last. And yet, exhibitions share with these other practices of commemoration their association to a particular place, even when they are moved from one capital city to the next. Despite being necessarily associated to a topographical location, statues and memorials are subject to change, as Sonnet 55 reminds us, and can be re-positioned too. There is no better example than Shakespeare's own memorial statue in his hometown. The Gower memorial in Stratford was originally designed for the garden of the Memorial Theatre, but today it stands in another location and the disposition of the Shakespearean characters is very different from that which the sculptor intended. ${ }^{9}$

Pierre Nora has argued that "Statues or monuments to the dead, for instance, owe their meaning to their intrinsic existence; even though their location is far from arbitrary, one could justify relocating them without altering their meaning."10 This is not exactly the case for the Gower memorial - relocation to the garden by the river bank has removed the close connection that existed before between memorial

\footnotetext{
9 See Hoenselaars, “The Pierre Fournier Shakespeare Statue”, op. cit., passim.

10 Pierre Nora, "Between Memory and History: Les Lieux de Mémoire", Representations 26 (1989), p. 7-24; 22
} 
statue and memorial theatre - today, the Gower memorial is a monument to a national poet, not the statue of a playwright. The new disposition of the characters has removed them from their close relation to their author - now they stand on their own, at a distance from their creator (Fig. 3). In spite of their mobility, then, all these commemorative practices - statues, memorials, cenotaphs, - cannot exist without a precise location - to exist they need to materialise over space, they require a material site, no matter how non-permanent or provisional. It is their relation to the space they inhabit that often creates new layers of memory and meaning.

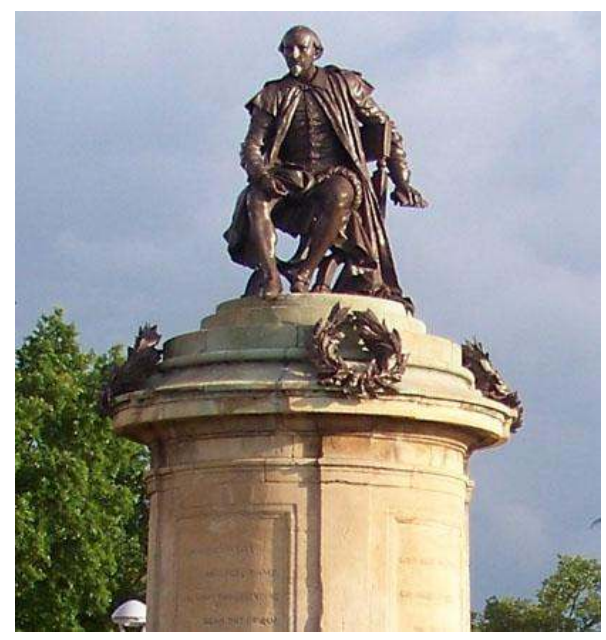

Figure 3: The Gower Memorial in Stratford-upon-Avon

\section{Shakespeare as grand homme}

Unlike the memorials for Rousseau and Voltaire at the Panthéon, Shakespeare's memorial in Poets' Corner is a cenotaph, not a grave. Although, the Panthéon and Poets' Corner fulfil the same function as national site of memory for their respective grands hommes, as lieux de mémoire central to the nation's collective identity they could not be more different. The Panthéon stands alone on an often deserted mountain top and one is likely to find there, as Jean Grecq put it "three 
shivering tourists from Illinois and nothing else."11 Memories of Poets' Corner begin instead with the hurdles of tourists queuing outside Westminster Abbey. Inside, beside mass tourism, other things make the experience of visiting the tomb of Rousseau as grand homme in the Panthéon very different from visiting Shakespeare's cenotaph as national poet in London. Whereas the Panthéon is a republican monument, the Abbey is a monument dedicated to monarchy. The Panthéon clinically divides its republican grands hommes from the monarchs and heroes, commemorated elsewhere. The Abbey brings under the same roof royalty and commoners, strengthening this link in the case of Shakespeare, whose cenotaph memorialises with sculpted portraits three English monarchs: Elizabeth, Henry V and Richard III. Nevertheless, Poets' Corner has been tucked away in the Abbey and there, as Nicola Watson reminds us, graves, cenotaphs and memorial plaques are jumbled together, as if one had entered by mistake into the lumber-room of English letters. ${ }^{12}$ Shakespeare's memorial in this English Panthéon is significantly different from the bust that adorns the wall to the left of his grave in Stratford. In London, he is memorialised as a man of letters, as a dignified eighteenth-century literary gentleman, whereas in Stratford he appears - except, perhaps, for the quill in his hand - as a contented, well-fed Jacobean landowner. Popular imagination has repeatedly appropriated and used the figure of Shakespeare and turned it into an icon, but the image selected to represent the icon has changed through time, revealing an intriguing evolution in the repertoire. Initially, the bust in Trinity Church provided the image of Shakespeare. Then the ritual function of representing the iconic image of the national poet was transferred to the Memorial in Poets' Corner, its copy in Leicester Square crucially contributing to memorialise the cenotaph. Finally, the First Folio engraved portrait by Droeshout superseded other iconic representations of Shakespeare.

Around the time of the 1864 anniversary celebrations, the bust over Shakespeare's grave provided the iconic image of the playwright, as shown by the official seal of the National Shakespeare Committee for

\footnotetext{
${ }^{11}$ Quoted in Mona Ozouf, “The Panthéon: The École Normale of the Dead”, in Pierre Nora, ed., Realms of Memory, vol. 3, p. 325.

12 For a shrewd cultural analysis of Poets' Corner, see Nicola Watson, The Literary Tourist: Readers and Places in Romantic and Victorian England, London, Palgrave, 2006.
} 
the 1864 Tercentenary and the well-known Punch cartoon with the caption "Shakespeare and the Pigmies" targeted at the Shakespeare Memorial Committee. ${ }^{13}$ Later, towards the end of the century, Scheemakers' statue in Poets' Corner clearly took over, judging from several comic cartoons. A satirical cartoon by William Kerridge Haselden which appeared in the Daily Mirror uses the statue to ridicule the proliferation of candidates to whom Shakespeare's plays have been attributed. ${ }^{14}$

Several years before, another Punch cartoon with the caption "Man and Superman - All the World's a Stage Society" made use of the same statue to laugh at Shaw's self-aggrandising nature. The cartoon portrays Shaw leaning on Shakespeare's statue in Poets' Corner and adopting Shakespeare's pose, but Shaw's figure has been made twice as big as Shakespeare's. The Memorial Statue in the Poets' Corner cenotaph was also depicted in yet another satirical cartoon in 1892 showing Oscar Wilde leaning on a pedestal, emulating Shakespeare in the Scheemakers and Kent cenotaph (Fig. 4).

In this satirical drawing, Shakespeare is memorialised in absentia. The subject of the cartoon and the target of the satire is Oscar Wilde, not Shakespeare, but as in the actual cenotaph in Poets' Corner, the absent body triggers the remembrance of the real one. Shakespeare is memorialised as the hypercanonical author to whose status Oscar Wilde aspires. Shakespeare is after all present in this parodic cartoon, in the form of the bust at the base of the pedestal. Shakespeare has now taken over the place of monarchs in his own cenotaph - this is Carlyle's King Shakespeare, Shakespeare as the royalty of letters, the aristocracy of literature. ${ }^{15}$

\footnotetext{
13 Punch, 30 January 1864.

14 Daily Mirror, 28 September 1925. See British Cartoon Archive:

http://www.cartoons.ac.uk/record/WH3654

15 "This King Shakespeare does he not shine, in crowned sovereignty, over us all, as the noblest, gentlest, yet strongest of rallying-signs; indestructible; really more valuable in that point of view than any other means or appliance whatsoever? We can fancy him as radiant aloft over all Nations of Englishmen, thousand years hence. From Paramatta, from New York, wheresoever, under what sort of Parish-Constable soever, English men and women are, they will say to one another, 'Yes, this Shakespeare is ours; we produced him, we speak and think by him; we are of one blood and kind with him."' (Thomas Carlyle, The Hero as Poet, 1841).
} 


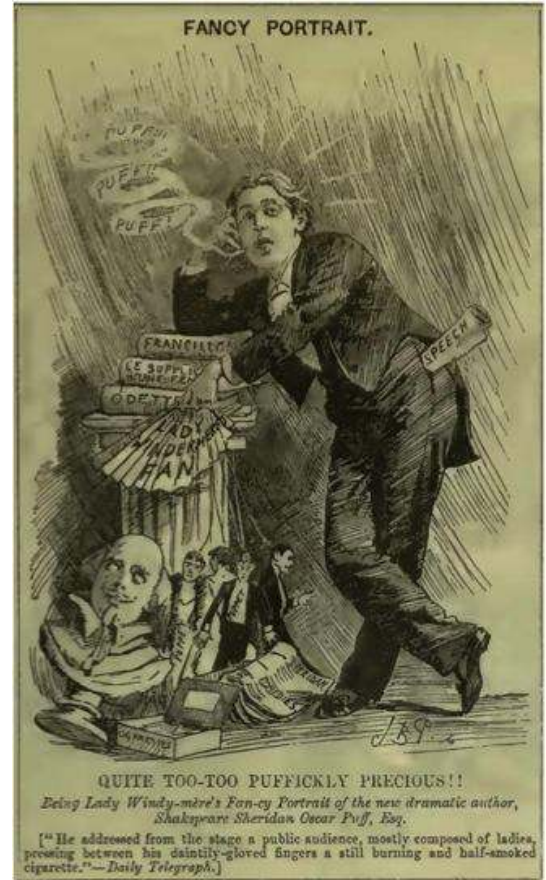

Figure 4: 1892 cartoon presenting Oscar Wilde adopting Scheemakers' statue's pose

Post-1960s popular culture has completely replaced Scheemakers' statue with the Droeshout engraving, as Banksy's famous graffitti portrait of Shakespeare's with aviator sunglasses on a wall in Nolita, Lower East Side Manhattan, shows. This evolution signals a move from the grave to the text through the cenotaph. The greater respect for the words of Shakespeare that characterised the late Victorian and Edwardian periods, to which William Poel's antiquarianism ${ }^{16}$ contributed, leads in the $20^{\text {th }}$ century to the enthronement of the First Folio as secular scripture.

16 William Poel (1852-1934), founder of the Elizabethan Stage Society, is well-known for claiming that the drama of Shakespeare and his contemporaries is best understood if staged under conditions as similar as possible to those of the early modern stage. He put this belief into practice, and from the 188 os he produced plays in Elizabethan costume with no scenery, often using Elizabethan venues such as the halls of the Inns of Court as stages or, as in 1893 at the Royal Theatre, a stage reconstruction of the drawing of the Swan by 
The canonicity of the First Folio engraving as the image of Shakespeare is occasionally challenged by the Chandos portrait. Invoking the Chandos portrait constitutes a conscious challenge to an established ritualistic practice, as the portrait by Mirko Ilic published by The New York Times in 1996 suggests. ${ }^{17}$ The portrait appeared in the "Sunday books" review section, next to a column on the timelessness of Shakespeare's works. Here, Shakespeare's face and hair evoke the Folio engraving while the earring is an evident homage to the Chandos portrait. The biker's jacket, the marihuana leaf tee-shirt and the piercing on the eyebrow may be meant to turn Shakespeare into our contemporary, but for this, the background of Times Square would have been enough. The choice of alternative clothes - instead of, for instance, a sharp business suit - memorialises Shakespeare as a popular playwright instead of a middle class impresario and partner in a player's company. Together, the Banksy and the Mirko Ilic portraits confirm the demise of the Poets' Corner monument as the iconic image of Shakespeare - the tri-dimensional cenotaph has given way to the two-dimensional portrait printed on the hypercanonical Folio, which functions today as a portable site of memory.

\section{Memorialising Shakespeare as Elizabethan}

Shakespeare's other cenotaph in London is secluded on the south aisle of Southwark cathedral and consists of a recumbent alabaster figure carved in 1912 by Henry McCarthy. Here, he is portrayed reclining, evoking an Elizabethan young lover out of a Hilliard miniature. Shakespeare's image is meant to recall the Elizabethan funeral effigy, with the deceased represented in the "tooth-ache" position, as in the tomb of Sir Edmund Fettiplace (d. 1613). He wears a doublet and hose and rosemary sprigs - a symbol of remembrance - have been freshly cut and put in his hand (Fig. 5).

Johannes de Witt. Poel's belief that the plays should be performed as they were performed in Shakespeare's London also directed attention to the text, and contributed to the move away from the excessive cutting and adaptation of Victorian productions. See Robert Speight, William Poel and the Elizabethan Revival, Cambridge, Mass, Harvard University Press, 1954, and Claris Glick, "William Poel: His Theories and Influence", Shakespeare Quarterly 15.1 (Winter, 1964), p. 15-25.

17 Reproduced in Mirko Ilic, Fist to Face, New York, Print, 2012, p. 166. 


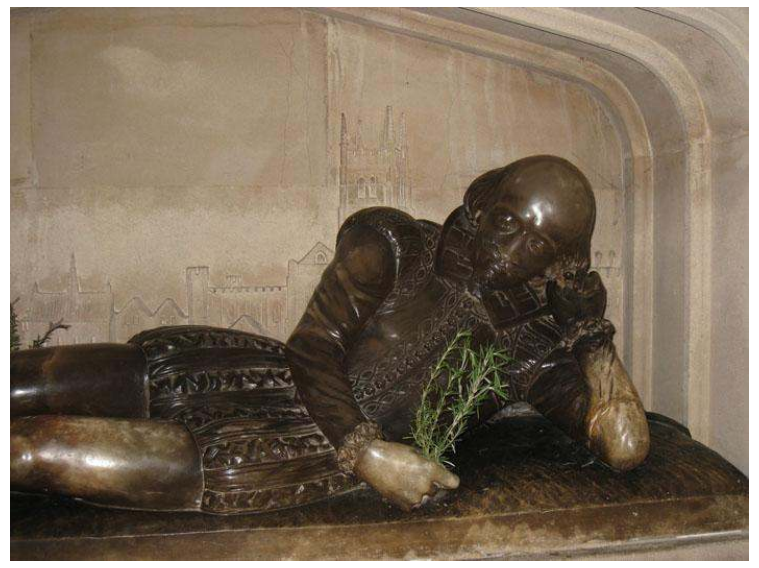

Figure 5: Henry McCarthy's statue in Southwark cathedral

This memorialisation of Shakespeare as the Elizabethan lover is underlined by the relief behind his back that connects him to early modern London and the theatre scene - this is after all the church in which his brother Edmund was buried in 1607. The relief behind shows the Globe theatre, Winchester Palace and the tower of St. Saviour's, the church that stood in Shakespeare's time where the Cathedral now stands. Unlike the bust in Stratford or Scheemakers and Kent's memorial in Poets' Corner, the Southwark memorial clearly directs remembrance toward Shakespeare's professional life in London as a man of the theatre. This is underlined by the stained-glass window, destroyed in the Blitz and replaced in 1954, which shows several characters from the plays, including Prospero and Caliban, Lear, Hamlet with the skull of Yorick and Lady Macbeth (Fig. 6). Every $23^{\text {rd }}$ of April, a commemorative ceremony is carried out in front of the cenotaph, the absence of a body being no deterrent for the enactment of the ritual. ${ }^{18}$

\footnotetext{
18 For a study of the genealogy of Southwark Shakespeare Memorial see Brian Walsh, "Shakespeare in Stained Glass: The Shakespeare Memorials of Southwark Cathedral and 'Local' Bardolatry”, Borrowers and Lenders, 7: 1 (2012).

http://www.borrowers.uga.edu/cocoon/borrowers/request?id $=783058$
} 


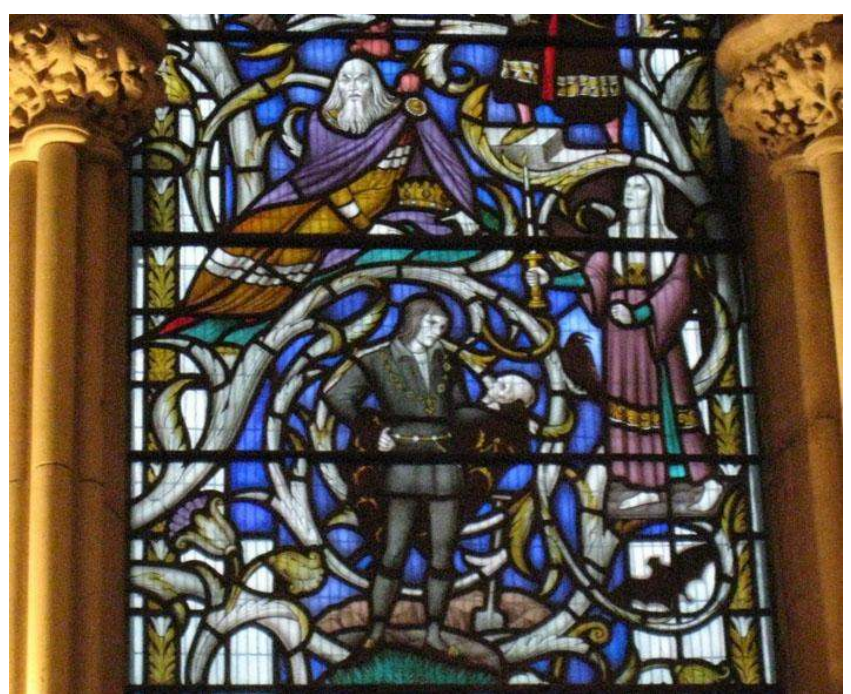

Figure 6: Stained-glass window depicting Hamlet, Lear and Lady Macbeth

Around the year when this memorial was carved, the Shakespeare's England exhibition was inaugurated at Earl's Court. The exhibition was arranged by Mrs. George Cornwallis West, Winston Churchill's mother, for the purpose of raising funds towards the National Theatre Committee. The Southwark memorial and the Shakespeare's England exhibition at Earl's Court stem from the same drive for antiquarianism that led William Poel to perform Elizabethan performance in replica stages. The Earl's Court exhibition twins Shakespeare with Elizabethan England through the central place allocated to the Revenge, Sir Francis Drake's ship during the Armada, just like the memorial in Poets' Corner links Shakespeare with Elizabeth, but not with James I, even though Shakespeare wore the royal livery and his company was called the King's Men. At Earl's Court, the architect Sir Edward Lutyens also erected a half-size replica of an early modern theatre inspired from the Globe. ${ }^{19}$

Both the Southwark cenotaph and the Earl's Court exhibition memorialise Shakespeare through Elizabethan England, or rather,

19 Marion F. O'Connor, “Theatre of the Empire: 'Shakespeare's England' at Earl's Court, 1912”, in Jean Howard and Marion F. O'Connor, eds., Shakespeare Reproduced: The Text in History and Ideology, London, Methuen, 1987, p. 68-98. 
through the musée imaginaire of the Edwardian obsession with England's Tudor past, as the mythical origin of its imperial present. Both the bas-relief behind Shakespeare's recumbent figure and Lutyens's reconstruction betray nostalgia for the Globe, as foundational myth of a national dramatic tradition. Both of them are also indirectly related to the projected National Theatre which was never built in time for the 1916 Tercentenary. The Southwark memorial was erected precisely at the time when the National Theatre campaigners opposed the erection of a monument to Shakespeare in London and the Earl's Court exhibition was arranged partly as a charity to collect funds for the Shakespeare Memorial National Theatre Committee.

When discussed together, the Southwark Cenotaph and the 1912 Earl's Court Shakespeare's England exhibition beg the question of why Shakespeare is so often memorialised through his association with Elizabethan England and only rarely through his mature life as an artist in Jacobean London. His most famous tragedies, with the exception of Hamlet and Romeo and Juliet, were written in the reign of James I. In spite of this, collective memory repeatedly associates Shakespeare with the Globe - and often with the 1614 Globe -and very infrequently with the Blackfriars theatre. A rare exception is the peculiar memorial to be found in a London city church, the church of St. Andrew's by the Wardrobe. ${ }^{20}$ In this unusual memorial Shakespeare is kneeling to pray and two cherubs hold back the curtains on each side. Underneath, a legend connects Shakespeare to the Blackfriars theatre and points out his ownership of a house in the parish, in Ireland Street. Popular culture, however, refuses to picture Shakespeare's plays in an indoor stage. Amateur Shakespeare, in particular, has always been extremely fond of open-air Shakespeare, as if the true essence of Shakespeare existed in unroofed performance. In this respect, Poel's decision to celebrate the 1916 Tercentenary in Middle Temple with a performance of Poetaster and not with a production of a play by Shakespeare becomes more meaningful. As a play not by Shakespeare, but a play about Shakespeare, Poetaster is clearly appropriate for an occasion on which the man and not the plays take centre stage in the commemorative proceedings.

\footnotetext{
${ }^{20}$ http://www.standrewbythewardrobe.net/shakespeare
} 
Shakespeare is memorialised through Elizabethan England and the Globe rather than through Jacobean culture and the Blackfriars because collective cultural memory finds more comfort in construing the past as different, and perhaps, as different as possible. The past, as David Lowenthal reminds us is a foreign country and the Globe, not Blackfriars, provides that element of memorialisation that demands difference from the present for nostalgia to operate. ${ }^{21}$ If the Shakespeare's England exhibition at Earl's Court used the past to foster the interests of the present, as Marion O'Connor has suggested, ${ }^{22}$ it also used the Elizabethan past to memorialise Shakespeare in the present, placing him centrally in an organic society in which all classes mingled in a happy togetherness. The sense of communality conveyed by the performances in Lutyens's replica of the Globe helped to preserve the Tudor myth, the Elizabethan world picture, for Edwardian society, but they also memorialised Shakespeare as a classless writer. To have linked Shakespeare with Jacobean London would have meant to associate him with decadence, aesthetic derivativeness, melancholy and even violence. More importantly, to associate Shakespeare with a replica of Blackfriars would have meant presenting him as a playwright catering for an aristocratic and upper-class audience and as an elitist, exclusive and excluding author.

As a constructed lieu de mémoire, Shakespeare is shaped out of remembering and forgetting specific topographical sites of memory. Rites of memory link Shakespeare to the open-air Globe but rarely to the candle-lit Blackfriars. Tourists in Stratford-upon-Avon visit the Birthplace - and less frequently Shakespeare's own house, New Place. Visitors to the reconstructed Globe on the Southbank commemorate Shakespeare with a tour, an ice-cream and possibly a play, but they are unlikely to walk to the nearby Park Street in search of the plaque that commemorates the real, original site of the Globe in an estate of council houses (Fig. 7). ${ }^{23}$

\footnotetext{
${ }^{21}$ David Lowenthal, The Past is a Foreign Country, Cambridge, C.U.P., 1985.

22 Marion F. O'Connor, "Theatre of the Empire: Shakespeare's England at Earl's Court, 1912", in Shakespeare's Reproduced: The Text in History and Ideology, ed. Jean E. Howard and Marion F. O'Connor, New York, Methuen, 1987, p. 68-98.

23 In 1942, when Sam Wanamaker traced the site of the original Globe, it was still, and appropriately, a brewery.
} 


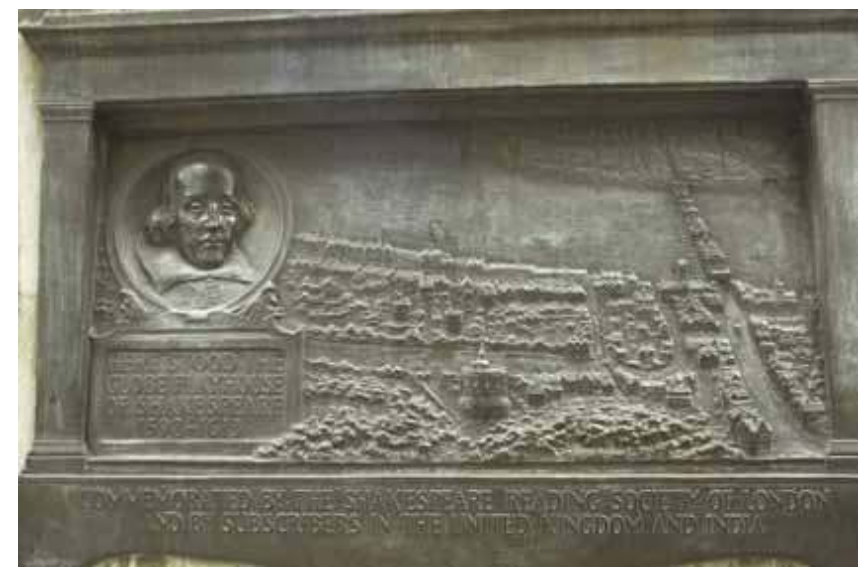

Figure 7: Plaque commemorating the original site of the Globe

Like the cenotaph at Rue Pasquier, the original site of the Globe is today an empty grave, triggering remembrance through absence. Like the graves of the French monarchs Louis XVI and MarieAntoinette, the Globe has been relocated, altering the meaning of the original site of memory, whose role in commemorative practice and collective cultural memory is now minimal. The original site of the Globe has become a remote, quasi-forgotten lieu de mémoire, which has not been excavated, like the Rose Theatre or New Place, and whose archaeological treasures remain silent, having no part to play in commemorative practice.

Clara Calvo University of Murcia (Spain) 